Al Maal : Journal of Islamic Economics and Banking

http://jurnal.umt.ac.id/index.php/jieb

E-ISSN : $2580-3816$

Vol : No 1 Vol 2 Bulan Januari Tahun 2020

Hlm : $176-186$

DOI $\quad$ : $10.31000 /$ almaal.v1i2.2274

\title{
Peran Amil Zakat dalam Meningkatkan Kesadaran Zakat Profesi Pada Laznas Al-Azhar Jakarta Selatan
}

\author{
Wisnu Nugraha ${ }^{1 *}$, Muhammad Zen² \\ ${ }^{1}$ Pemerhati Zakat dan Amil Zakat Laznas Al-Azhar, Jakarta, Indonesia, \\ ${ }^{2}$ UIN Syarif Hidayatullah, Jakarta, Indonesia \\ *wisnuraha99@gmail.com
}

\begin{abstract}
The purpose of this research is for knowing the jobs and the position of zakat agency, the function of zakat agency in increasing awareness of profession zakat, contributing factors and presecutor factors. This research used qualitative method by analysing of descriptive data. The researcher gave a description of discovery which was found by Laznas Al-Azhar. This research used data collection by observation in the location, interviewing and be completed by data documentation. The result of the function of zakat agency in increasing awareness of profession zakat is all zakat agencies have been doing their jobs professionally and zakat agency of Laznas Al-Azhar has the important contribution in increasing awareness of profession zakat. The position of zakat agency is the best and the main function of zakat agency is same generally, it is giving education. While from their jobs are accumulation, writing down, managing and distribution for mustahik as eight asnaf which is from Al-Quran.
\end{abstract}

Keywords: LaznasAl-Azhar; Zakat agency; The function; Profession; Zakat.

\begin{abstract}
ABSTRAK
Tujuan dari penelitian ini adalah untuk mengetahui tugas dan kedudukan amil, peran amil dalam meningkatkan kesadaran zakat profesi serta faktor-faktor pendukung dan penghambatnya pada laznas Al-Azhar. Penelitian ini menggunakan pendekatan penelitian kualitatif dengan teknik analisis data deskriptif. Penelti memberikan deskripsi dari sutu temuan yang di peroleh dari laznas Al-azhar. Penelitian ini menggunakan teknik pengumpulan data melalui observasi di lapangan, wawancara dan dilengkapi dengan data dokumentasi. Hasil dari penelitian peran amil dalam meningkatkan kesadaran zakat profesi pada Laznas Al-Azhar adalah seluruh amil sudah menjalankan tugasnya secara profesional dan amil yang ada di Laznas Al-Azhar sangat berperan penting dalam peningkatan kesadaran muzaki untuk berzakat. Kedudukan amil sangat mulia dan peran utama amil secra umum sama, yaitu memberikan edukasi. Sedangkan dari tugasnya adalah menghimpun, mencatat, mengelola dan mendistribusikan kepada mustahik sesuai dengn delapan asnaf yang ada dalam Al-Quran.
\end{abstract}

Kata kunci: Laznas Al-Azhar; Amil; Peran; Profesi; Zakat. 


\section{Pendahuluan}

Indonesia merupakan suatu negara yang sangat besar baik dari segi wilayah dan jumlah penduduknya, ini menandakan negara Indonesia sangat potensial untuk bisa menjadi negara yang maju, dengan di dukung oleh sumber daya manusia yang memiliki kemampuan dan integritas yang tinggi dalam segala bidang, baik itu bidang ekonomi, sosial, politik, budaya dan lain sebagainya. Selain sumber daya alam, sumber daya manusia adalah faktor terpenting dalam pertumbuhan ekonomi. Pertubuhan ekonomi tidak semata-mata tergantung pada sumberdaya manusia saja, tetapi lebih ditekankan pada efisiensi penetapan SDM. Untuk mendorong agar sumber daya manusia dapat bekerja secara efisien dan maksimal, maka di perlukan pembentukan manusia, yaitu proses peningkatan ilmu pengetahuan, keterampilan dan kemampuan seluruh penduduk negara/wilayah yang bersangkutan (Idris,2016).

Islam merupakan agama yang bersifat rahmatan lil'alamin, ajaran Islam mencakup hubungan manusia dengan tuhannya yang di kenal dengan istilah ibadah, dan hubungan manusia dengan sesamanya disebut muamalah, salahsatu aspek kegiatan muamalah dalam kehidupan manusia dilaksanakan dalam bentuk kegiatan ekonomi, yaitu kegiatan yang bertujuan untuk memudahkan manusia dalam memenuhi berbagai bentuk kebutuhan dan keinginan hidupnya.

Secara umum pengertian ekonomi adalah salahsatu ilmu sosial yang mempelajari aktivitas manusia yang berhubungan dengan produksi, distribusi dan konsumsi terhadap barang dan jasa. Di Indonesia penggunaan ekonomi Islam terkadang digunakan bergantian dengan istilah ekonomi syariah (Prasetyo, 2018). Dikaitkan dengan zakat, zakat adalah ibadah maaliyyah ijtima'iyyah yang memiliki posisi yang sangat penting, strategis dan menentukan, baik dilihat dari sisi ajaran Islam maupun dilihat dari sisi kesejahtraan umat. Sebagai salahsatu ibadah pokok, zakat merupakan salahsatu rukun (rukun ketiga) dari rukun Islam yang lima, sebagaimana diungkapkan dalam berbagai hadist Nabi sehingga keberadaanya dianggap sebagai ma'lum minad-diin bidh-dharuurah atau diketahui secara otomatis adanya dan merupakan bagian mutlak dari seseorang (Hafidhuddin, 2002).

Pada zaman sekarang ini orang mendapatkan uang dari pekerjaan dan profesinya. Jadi pekerjaan yang menghsilkan uang ada dua macam. Pertama adalah pekerjaan yang dikerjakan sendiri tanpa menggantungkan diri kepada orang lain, seperti seorang dokter yang mengadakan praktik, pengacara, seniman, penjahit, dan lain-lain. Kedua pekerjaan yang dikerjakan untuk orang (pihak) lain dengan imbalan mendapat upah atau honorarium, seperti pegawai negri atau swasta (Hasan, 2006).

Potensi zakat masyarakat Indonesia mencapai Rp. 7,2 Trilyun per tahun. Berdasarkan hasil survey UIN Syarif Hidayatullah Jakarta tentang potensi zakat msyarakat Indonesia sebesar Rp. 19,3 Trilyun per tahun. Dr. Anggito Abimanyu memprediksi potensi zakat masyarakat Indonesia Rp. 7,3 Trilyun pertahun dengan catatan 100\% wajib zakat di Indonesia patuh untuk membayarnya (Julijanto, 2015).

Melihat potensi tersebut, seharusnya banyak masyarakat yang mengeluarkan zakat, tetapi ternyata dikalangan masyarakat muslim Indonesia masih banyak yang belum menegetahui tentang zakat profesi, sehingga dari pemahaman yang kurang akan menimbulkan ketidaksadaran untuk mengeluarkan zakat. Dalam hal ini tentunya ada tugas dan peran amil untuk bisa berupaya menyelesaikan permasalahan yang ada saat ini, seperti memberikan edukasi dan lain-lain. Sehingga muzaki bisa lebih mengetahui dan 
memahami tentang zakat (khususnya zakat profesi) dan bisanga mengeluarkan zakatnya sesuai dengan aturan-aturan yang ada.

\section{KAJIAN LITERATUR Pengertian Peran}

Menurut kamus besar Bahasa Indonesia peran adalah beberapa tingkah laku yang diharapkan dimiliki seseorang yang berkedudukan di masyarakat. Sedangkan dalam kamus ilmiyah populer, peran mempunyai arti "orang yang dianggap sangat berpengeruh dalam kelompok masyarakat dan menyumbangkan pemikiran atau tenaga demi suatu tujuan".

Adapun makna dari kata "peran" dapat di perjelas melalui beberapa cara. Pertama, suatu penjelasan historis menyebutkan, konsep peran semula dipinjam dari kalangan drama atau teater yang hidup subur pada zaman Yunani kuno atau Romawi. Dalam arti ini, peran menunjuk pada karakterisasi yang disandang untuk dibawakan oleh seorang aktor untuk di pentaskan dalam sebuah drama. Kedua, suatu penjelasan yang menunjuk pada konotasi ilmu sosial, yang mengertikan peran pada suatu fungsi yang dibawakan seorang ketika menduduki suatu karakterisasi (posisi) dalam struktur sosial Ketiga, suatu penjelasan yang bersifat operasional, menyebutkan bahwa peran seorang aktor adalah suatu batasan yang dirancang oleh aktor lain, yang kebetulan sama-sama berada dalam satu "penampilan/unjuk peran" (role performance). Hubungan antar pelaku (aktor) dan pasangan laku perannya (role partner) bersifat saling terkait dan saling mengisi, karena dalam kontes sosial, tidak satu peranpun dapat berdiri sendiri tanpa yang lain. Dengan ungkapan lain, suatu peran akan memenuhi keberadaanya, jika berada dalam kaitan posisional yang menyertakan dua pelaku peran yang komplementer (Suhardono,2016).

Berdasarkan pemaparan di atas dapat disimpulkan bahwa peran merupakan pengaruh seseorang yang memiliki jabatan tertentu pada suatu kelompok dengan perilaku dan pemikirannya bisa membuat perubahan untuk mencapai suatu tujuan.

\section{Pengertian Amil Zakat}

Menurut Yusuf al-Qardhawi, yang dimaksud dengan amil zakat ialah mereka yang melaksanakan kegiatan urusan zakat. Mulai dari para pengumpul sampai kepada bendahara, aparat penjaganya, juga mulai dari pencatatan sampai penghitung yang mencatat keluar masuk zakat dan membagi kepada para mustahik (Al-Qardhawi,1976).

Para amil zakat mempunyai tugas dan pekerjaan, semuanya berhubngan dengan pengaturan soal zakat yaitu soal sensus terhadap orang yang wajib zakat dan macam zakat yang diwajibkan padanya, juga besar zakat yang wajib di zakati, kemudian mengetahui para mustahik zakat. Berapa jumlah mereka berapa kebutuhan meraka serta besar biaya yang dapat mencakupi dan hal lain yang merupakan urusan yang perlu ditangani secara sempurna oleh para ahli dan petugas serta para pembantunya (Al-Qardhawi,1976).

Amil adalah orang atau sekelompok orang atau intuisi yang bertugas mengumpulkan, mendistribusikan dan mendayagunakan zakat. Dalam UU nomor 21 tahun 2011 tentang pengelolaan zakat yang dimaksud dengan amil zakat adalah Badan Amil Zakat (BAZ) yang di bentuk pemerntah dari tingkat pusat sapai tingkat kecamatan 
dan Lembaga Amil Zakat (LAZ) yang dibentuk masyarakat dan dikukuhkan pemerintah (Kemenag, 2012).

Sementara Fatwa Majelis Ulama Indonesia Nomor 8 Tahun 2011 Tentang amil zakat menjelskan bahwa amil zakat adalah seorang atau sekelompok orang yang diangkat oleh Pemerintah untuk mengelola pelaksanaan ibadah zakat atau seseorang atuau kelompok orang yang dibentuk oleh masyarakat dan disahkan oleh Pemerintah untuk mengelola pelaksanaan ibadah zakat (Fatwa Majelis Ulama Indonesia, 2011)

Berdasarkan pemaparan di atas amil adalah seorang petugas dari ulil amri yang bekerja tentang kegiatan zakat, dari mulai administrasi, menghimpun dari orang wajib zakat (muzaki), menghitung, mengelola dan mendistribusikan kepada penerima zakat (mustahik) dengan tujuan mampu menjadikan mustahik menjadi mzaki.

\section{Pengertian Zakat}

Pengertian zakat ditinjau dari segi bahasa memiliki bebebrapa arti, yaitu albarakatu yang artinya keberkahan, alnama yang artinya pertumbuhan dan perkembangan, ath-thaharatu yang berarti kesucian, dan ash-shalahu yang artinya keberesan. Sedangkan menurut istilah, zakat merupakan bagaian dari harta dengan persyaratan tertentu yang diwajibkan Allah SWT utuk diberikan kepada yang berhak menerimanya sesuai denga ketentuan pada Al-Quran surah At-taubah ayat 60 (Utomo, 2009).

Secara lahiririah, zakat mengurangi nilai nominal (harta) dengan mengeluarkannya, tetapi dibalik pengurangan yang bersifat dzair ini hakikatnyaakan bertambah dan berkembang (nilai instinsik) yang hakiki disisi Allah SWT. Zakat merupakan ibadah yang memiliki dimensi ganda, transendental dan horizontal. Oleh sebab itu zakat memiliki banyak arti dalam kehidupan umat manusia, terutama umat Islam (Zen, 2005)

Zakat menurut terminologi syariat adalah nama bagi sejumlah harta tertentu yang telah mencapai syarat tertentu yang diwajibkan oleh Allah untuk dikeluarkan dan diberikan kepada yang berhak menerimanya dengan persyaratan tertentu pula (Hafifudin, 2002). Zakat berarti juga derma yang telah di tetapkan jenis, jumlah, dan waktu suatu kekayaan atau harta yang wajib diserahkan dan pendayagunaanpun ditentukan pula, yaitu dari umat Islam untuk umat Islam (Zen, 2010).

Jadi menurut penulis zakat adalah sejumlah harta seorang muslim yang wajib diberikan kepada penerima tertentu dengan syarat tertentu sesuai syariat. Harta berambah dan berkembang secara hakikat serta bernilai ibadah bagi yang mengeluarkanya.

\section{Pengertian Profesi}

Menurut Wikipedia Profesi adalah kata serapan dari sebuah kata dalam bahasa

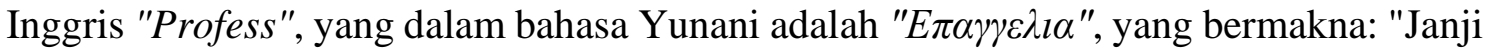
untuk memenuhi kewajiban melakukan suatu tugas khusus secara tetap/permanen". Profesi juga sebagai pekerjaan yang membutuhkan pelatihan dan penguasaan terhadap suatu pengetahuan khusus. Suatu profesi biasanya memiliki asosiasi profesi, kode etik, serta proses sertifikasi dan lisensi yang khusus untuk bidang profesi tersebut. Contoh profesi adalah pada bidang hukum, kesehatan, keuangan, militer, teknik desainer, tenaga pendidik. 
Sedangkan menurut Kamus Besar Bahasa Indonesia kata profesi adalah bidang pekerjaan yang dilandasi bidang pendidikan keahlian (keterampilan, kejuruan, dan sebagainya) tertentu. Profesional adalah yang bersangkutan dengan profesi, memerlukan kepandaian khusus untuk menjalankanya.

Profesi dapat dirumuskan sebagi pekerjaan yang dilakukan sebagi nafkah hidup dengan mengendalikan keahlian dan keterampilan yang tinggi dengan melibatkan komitmen pribadi (moral) yang mendalam. Dengan demikian profesi memang sebuah pekerjaan pada umumnya. Profesi mempunyai tuntunan yang sangat tinggi, bukan saja diluar melainkan terutama dari dalam diri orang itu sendiri. Tuntunan itu menyangkut tidak hanya keadilan melainkan juga komitmen moral, tanggung jawab, keseriusan, disiplin, dan integritas pribadi (Keraf, 1998).

Profesi menurut penulis yaitu suatu pekerjaan yang sudah dikuasai serta diakui khalayak banyak, sudah tersertifikasi dalam dunia pendidikan yang pekerjaannya itu bisa menghasilkan berupa uang untuk kehidupannya atau kepercayaan dari orang lain.

\section{Pengertian Zakat Profesi}

Menurut Didin Hafidhuddin, "zakat profesi adalah zakat yang dikenakan pada tiap pekerjaan atau keahlian profesional tertentu, baik yang dilakukan sendiri maupun dilakukan bersama, dengan orang atau lembaga lain, yang mendatangkan penghasilan (uang) yang memenuhi nisab (Hafidhuddin, 1998). Zakat profesi merupakan al-maal almustafad dimana zakat yang dikeluarkan dari hasil usaha yang halal yang dapat mendatangkan hasil (uang) yang relatif banyak dengan cara yang mudah, melaui suatu keahlian tertentu dan sudah mencapai nishab dengan demikian yang dimaksud al-maal al-mustafad adalah "zakat rofesi" atau zakat hasil kerja dari pekerjaan-pekerjaan yang bergerak dibidang jasa seperti pegawai negeri pegawai perusahaan, dokter, pengacara dan sebagainya. Oleh karena itu ia harus di tarik zakatnya begitu diterima $1 / 40$-nya $(2,5 \%)$ (Zen, 2014).

Sementara fatwa ulama yang dihasilkan dari mukhtamar internasional pertama tentang zakat di Kuait pada tanggal 29 Rajab 1404 H. Yang dikutip oleh Didin Hafidhuddin bahwa salahsatu kegiatan profesi adalah yang menghasilkan amal yang bermanfaat, baik yang sendiri seperti dokter, arsitek dan lain-lainnya, maupun yang dilakukan secara bersama-sama, seperti para karyawan atau pegawai. Semua itu menghasilkan pendapatan atau gaji (Fakhrudin, 2008). Zakat profesi hukumnya adalah wajib atas rizki penghasilan yang di dapatkan sehingga kewajiban dari segala rizki yang telah Allah berikan dikeluarkan sehingga membuat pemiliknya berkecukupan atau kaya.dan semua sudah sepakat bahwa orang kaya wajib membayar zakat apalagi sudah terjadi pergeseran pendapat dalam ekonomi modern secara besar dalam jenis usaha yang dapat menghasilkan kekayaan (Zen, 2014).

Jadi dapat disimpulkan zakat profesi adalah zakat dari hasil pekerjaan tetap yang sudah lama dilakukan sehingga menjadi sebuah profesi baik yang sifatnya sendiri atau kelompok yang menghasilkan uang banyak. 


\section{HASil dan Pembahasan Tugas dan Kedudukan Amil Zakat Laznas Al-Azhar}

Fatwa Majelis Ulama Indonesia Nomor 8 Tahun 2011 Tentang amil zakat menerangkan bahwa amil zakat memiliki tugas: a). Penarikan/pengumpulan zakat yang meliputi pendataan wajib zakat, penentuan obek wajib zakat, besaran nisab zakat, besaran tarif zakat, dan syarat-syarat tertentu pada masing-masing ojek wajib zakat. b). Pemeliharaan zakat yang meliputi inventarisasi harta, pemeliharaan, serta pengamatan harta zakat dan c). Pendistribusian zakat meliputi penyaluran harta zakat agar sampai kepada mustahik zakat secara baik dan benar termasuk pelaporan.

Pertama Menghimpun. Pengertian menghimpun disini bisa diartikan memaksa atau memungut. Tapi di negara kita Indonesia bukanlah negara Islam. Negara ini mempuyai aturan, dalam undang-undang nomor 23 tahun 2011 tentang pengelolaan zakat. Pengambilan zakat dapat dilakukan secara baik, melakukan cara-cara yang elegan dan profesional. Kedua Mencatat. Dalam hal ini merupakan bagian penting yang harus dilakukn seorang amil, karena nantinya amil akan diminta pertanggungjawaban untuk kepentingan laporan kepada pemerintah dan kepada muzaki. Pencatatan di Laznas AlAzhar sendiri sudah menggunakan sistem aplikasi yang sudah otomatis terhitung dan terakumulasi sesuai dengan jenis-jenis zakat. Pencatatan data muzaki, mulai dari nama, alamat rumah, nomor terlepon, email dan lain sebagainya. Sehingga data ini akan menjadi data base laznas Al-Azhar yang bisa digunakan untuk kepentingan laporan.

Selain melakukan pencatatan, beradakwah, mengingatkan kepada yang belum sadar mengeluarkan zakat, tugas amil setelah muzaqi mengelurkan zakat adalah harus mendo'akan nya, karna didalam zakat juga ada ijab dan qobulnya. Sebagaimana firman Allah dalam al-Qur'an surat At-taubah ayat 103. Ketiga Mengelola. Ketika dana zakat, infak, sedekah, terkumpul, tugas selanjutnya adalah mengelolanya secara profesional dengan manajemen program yang baik, sebagaimana yang dilakukan oleh Baznas Laznas Al-Azhar terdapat Program Pengentasan Pengangguran \& Pemberdayaan Usia Produktif, Pemberdayaan Ekonomi, Infrastruktur dan Konservasi Lingkungan, dan Memperbaiki Kondisi Kehidupan Anak Yatim dan Dhuafa. Keempat Mendistribusikan. Amanah amil tidak hanya sebatas mencatat, mengumpulkan serta mengelola saja, tetapi harus di tuntaskan sampai kepada tahapan pendistribusian, karn amil merupakan jembatan antara muzaki dan mustahik.

Kalau bagi saya tugas amil itu adalah sebagai jembatan antara muzakki dan mustahik, kalau di lembaga amil zakat Al-Azhar sendiri tugas amil sangat penting, karena menyampaikan amanah dari muzakki kepada mustahiq, jadi amil itu sebagai perantara jembatan (Wawancara Pribadi, 2019)

Amil zakat sebagai orang yang menyalurkan zakat dituntut untuk memiliki integritas yang kuat dan berakhlak karimah. Mereka juga diizinkan untuk menggunakan metode apapun sesuai syariah, termasuk dengan metode digital. Tentu diperlukan usaha untuk memotong mata rantai kemiskinan. Bagi yang miskin karena tidak memiliki pendidikan, maka dana zakat digunakan untuk membangun sarana dan prasarana pendidikan. Selain itu amil zakat juga harus memiliki komitmen untuk memanfaatkan dana zakat sehingga dapat meningkatkan kesejahteraan mustahik. Ini karena ukuran keberhasilan penyaluran zakat adalah sejauh mana mustahik dapat menjadi muzaki. 
Tugas dan tanggung jawab amil zakat tidak hanya sebatas mengumpulkan zakat dan menyalurkan kepada penerima yang berhak, tetapi juga sekaligus memiliki tanggung jawab moral dan dakwah untuk mendidik masyarakat. Berbicara kedudukan amil, dijelaskan dalam Al-Quran surat at-taubah ayat 60 Allah berfirman:

Sesungguhnya zakat-zakat itu, hanyalah untuk orang-orang fakir, orang-orang miskin, pengurus-pengurus zakat, Para mu'allaf yang dibujuk hatinya, untuk (memerdekakan) budak, orang-orang yang berhutang, untuk jalan Allah dan untuk mereka yuang sedang dalam perjalanan, sebagai suatu ketetapan yang diwajibkan Allah, dan Allah Maha mengetahui lagi Maha Bijaksana.

\section{Peran Amil Zakat dalam Meingkatkan Kesadaran Zakat Profesi}

Amil adalah orang yang melaksanakan segala kegiatan urusan zakat, dimana Allah menyediakan upah bagi mereka dari zakat sebagai imbalan. Amil zakat dalam Islam bukanlah suatu tugas yang hanya diberikan kepada seseorang individual, tapi merupakan tugas jamaah bahkan menjadi tugas negara. Amil tetap diberi bagian zakat walau ia kaya, karena yang diberikan kepadanya adalah imbalan kerjanya bukan berupa pertolongan bagi yang memerlukan. Amil itu adalah pegawai, maka hendaklah diberi upah sesuai dengan pekerjaannya, tidak terlalu kecil dan tidak juga berlebihan. M Yusuf al-Qardhawi menyatakan bahwa bagiannya maksimal sebesar $1 / 8$ bagian.

Salahsatu pekerjaan yang disebut oleh Allah dalam Alquran adalah amil. Menjadi amil adalah pilihan, jika harta yang dicari, maka berapalah gaji dari amil. Namun jika keberkahan yang dicari, insyaAllah keberkahan akan didapatkan, karena amil merupakan perpanjangan tangan Allah. Sehingga kehidupan yang baik di dunia insyaAllah didapat. Sebab ukuran kebahagiaan bagi amil bukanlah harta, melainkan kebahagiaan batin. Amil akan tersenyum bahagia jika mampu menyalurkan harta zakat kepada orang yang berhak menerimahnya.

Jika masyarakat faham zakat, maka memudahkan tugas dari para amil, dengan sendirinya para muzaki akan memberikan zakatnya kepada lembaga amil zakat yang terpercaya, seperti Baznas yang tersebar di seluruh Indonesia ataupun lembaga zakat yang telah disyahkan oleh pemerintah keberadaannya sesuai dengan ketentuan peraturan dan undang-undang yang berlaku. Ketika zakat dikelolah secara profesional, oleh lembaga amil zakat terpercaya, maka zakat sangat berpengaruh signifikan terhadap pengurangan kemiskinan dan peningkatan kesejahteraan masyarakat. Peran amil zakat pengaruh serta manfaatnya sangat besar disebabkan amil merupakan petugas allah untuk jembatan peenyaluran harta dari muzaki kepada mustahik, tidak haya itu amil juga bisa membuat program yang produktif untuk kemaslahatan umat.

Sangat ironis jika masih ada umat Islam yang hanya tahu zakat fitrah saja setiap Idul Fitri. Faktanya di tengah banyaknya lembaga pengelola zakat masih ada kalangan umat Islam yang belum mengerti zakat mal yang wajib dikeluarkan dari harta dan penghasilannya

Berbicara peran tentunyaa semua peran petugas amil di semua lembaga sama, hanya saja kalau di laznas al-Azhar sendiri mengenai zakat profesi tidak terlalu di publish, lebih kepada edukasi secara umum, seperti yang diungkapkan oleh bapak Dika Lustian:

Zakat profesi kalau di Al-Azhar sih kita tidak tetap mengedukasi tentang zakat profesi, tetapi bagi orang-orang yang tidak sepaham dengan zakat profesi kita tidak 
membantahnya. Makanya kalau di kita ini bentuk komunikasinya tidak berbeda dengan lembaga-lembaga lain, kalau lembaga lain kan mungkin sedikit mempublish tentang zakat profesi kalau di Al-Azhar tidak. Dari segi komunikasinya dan publikasi, coba aja cek di katalog katalog tidak ada yang menyebut zakat profesi, tapi kalau ada orang yang mau bayar zakat profesi ya kita terima. Jadi kalau di kita ini netral mau dia bermadzhab zakat profesi mau nggak ya monggo. Nantinya kalau kita mempublikasikan zakat profesi nanti ya Al-Azhar mazhabnya zakat profesi, kita masih umum karena mereka kan punya mazhab atau dalil sendiri (Wawancara Pribadi, 2019)

Setiap yang bekerja di laznas Al-Azhar dari mulai direksi, pengurus, sampai kepada staff, itu semua dinamakan sebagai amil zakat. Dan setiap bagian punya peran yang sama, yaitu menjalankan apa yang diperintahkan Allah SWT, hanya saja setiap bagian memiiki tugas yang berbeda-beda. Contohnya seperti divisi funding, tugasnya itu mencari dana atau menghimpun dan mengedukasi muzaki agar bisa memahami tentang zakat sehingga bisa mengeluarkan zakatnya kepada laznas Al-Azhar.

Tetapi di Al-azhar sendiri menghimpun dana zakat bukanlah hal yang diutamakan melain kan semua petugas amil memiliki kewajiban untuk memberikan edukasi kepada masyarakat. Bagian keuangan misalnya, walupun tugas utamanya adalah mencatat tetapi ketika bertemu dengan muzaki tetap harus memiliki pemahaman juga untuk bisa memberikan edukasi tetntang zakat. Sedangkan divisi program tugasnya adalah menyalurkan amanah-amanah dari donatur. Di laznas Al-Azhar sendiri mengenai peran amil untuk meningkatkan zakat profesi yaitu memberikan penjelasan kepada muzaki tentang zakat profesi, bahwa zakat profesi itu berasal dari zakat pertanian, dalam hal ini masuk kepada zakat mall. Petugas amil memberikan pemahaman zakat profesi itu patokannya dari mana dan ketentuanya bagaimana. Selain memberikan penjelesan secara langsung, di laznas Al-azhar bisa mengeduksi melalui media, salasatunya ada media sosial, katalog, brosur dan lain sebagainya. Amil yang baik mampu mengembangkan ide inovatif berbentuk program. Sehingga uang yang sedikit bermanfaat untuk masyarakat banyak. Oleh sebab itu, seorang amil yang baik harus mampu untuk melakukan itu.

Sebagai tolak ukur amil laznas Al-Azhar berhasil dalam peran nya untuk meningktkan kesadaran zakat profesi yaitu dari banyaknya kesadaran orang untuk berzakat kepada laznas Al-Azhar dan terselenggaranya program unggulan yang ada di laznas Al-azhar. Dilihat dari produktivitas amil yang penulis teliti seluruh amil lznas alAzhar sudah melukan peran nya sesuai dengan tugasnya masing-masing, bisa dilihat dari program-program yang sudah terselenggra yaitu:

- Pengentasan Kemiskinan dan Pemberdayaan Masyarakat Desa

- Pengentasan Pengangguran \& Pemberdayaan Usia Produktif

- Pemberdayaan Ekonomi, Infrastruktur dan Konservasi Lingkungan

- Memperbaiki Kondisi Kehidupan Anak Yatim dan Dhuafa

- Penanggulangan Bencana dan Jaringan Relawan

Selain dari program diatas juga dilakukan program yang bersifat insedentil terhadap kebutuhan mustahik yang secara tiba-tiba perlu dibantu untuk kebutuhannya yang sangat mendesak, sebab ada sebagian mustahik yang harus diberikan dana secara langsung karena faktor darurat, jika tidak ditolong dapat berakibat fatal,seperti kematian. Bagi Laznas memberikan program pemberdayaan kepada mustahik lebih diprioritaskan, 
karena sifat keberlangsunganya cukup panjang. sehingga kontinyuinitas program berjalan terus.

\section{Faktor Pendukung dan Penghambat Amil Zakat dalam Meningkatkan Kesadaran}

\section{Zakat Profesi Pada Laznas Al-Azhar}

Faktor pendukung muzaki bisa mengeluarkan zakatnya kepada laznas al-azhar yaitu dengan adanya keselarasan tugas dan peran seluruh amil yang ada di laznas AlAzhar untuk memberikan edukasi paripurna kepada muzaki dengan berbagai cara komunikasi dan media dakwah yang ada di laznas Al-Azhar.

Pertama dengan media sosial, di laznas al-azhar terdapat media sosial Instagram, Twiter, Facebook dan Website. Kedua dengan eadukasi kajian TAMARSYA (Ta'lim Manajeman Harta Syariah). Ketiga membangun komuniksi dan sosialisasi dengan jami'ah orang tua murid dari sekolah al-Azhar. Dan hal yang paling mendukung dan umum tentunya dengan adanya keselarasan edukasi di semua lembaga baik itu Laznas, Baznas serta Laz. Dan kesamaan dalil kaidah yang sudah ditentuntukan didalam fiqih tentang zakat.

Sementara faktor penghabatnya yaitu karna pemahaman serta kualitas keimanan seseorang yang berbeda (naik turun). Berbicara mengenai keimanan, tentunya merupakan permasalahan terpenting seorang muslim, sebab iman menentukan nasib seorang didunia dan akhirat. Bahkan kebaikan dunia dan akherat bersandar kepada iman yang benar. Dengan iman seseorang akan mendapatkan kehidupan yang baik di dunia dan akherat serta keselamatan dari segala keburukan dan adzab Allah. Dengan iman seseorang akan mendapatkan pahala besar yang menjadi sebab masuk ke dalam surga dan selamat dari neraka.

Keimanan senantiasa naik turun. Saat iman naik, saat itulah seorng bisa taat, dan bisa mengeluarkan zakatnya, berbeda disaat iman nya turun, mungkin bisa enggn mengeluarkan zakat. Saat iman naik saat itulah bisa merasakan betapa lezatnya iman itu. Hidup terasa tenang, dada lapang, mata terasa sejuk, pikiran jernih, kata-kata manis, penuh tawakal, ibadah terasa ringan dan nikmat.

Semakin banyak sifat dan perbuatan buruk dilakukan semakin deras luncuran iman itu menuju titik terendah. Sebaliknya semakin tinggi kuantitas dan kualitas ketaatan semakin cepat iman itu menanjak ke puncak. Kemuadin selain faktor iman, faktor penghambatnya dipengaruhi juga dengn belum adanya peraturan dari pemerintah terkait dengan pembayaran zakat.

Faktor penghambatnya bagi saya sampai saat ini, tetap satu, yaitu belum ada gebrakan dari pemerintah terkait pembayaran zakat. Pemerintah kan lebih mendominasi kepada pajak dibandingkan zakat, jadi peran pemerintah itu sangat penting untuk mengedukasi masyarakat terkait zakat, pasti kan pemerintah punya data mana yang kategori miskin mana kategori mampu, mana kategori kaya, seharusnya ketika punya data kategori orang yang mampu itulah yang ditarik zakatnya, tugas yang menarik zakat ya baznas dan laz pemerintah punya otoriter (Wawancara Pribadi, 2019)

Pemerintah hanya berencana menerbitkan regulasi tentang optimalisasi penghimpunan zakat Aparatur Sipil Negara (ASN) Muslim. Aturan itu diklaim hanya akan memfasilitasi para ASN untuk menunaikan zakat dan hanya sebagian ASN saja. 
Jikalau pemerintah membuat kebijakan tentang zakat sama halnya seperti pajak tentunya LAZ akan lebih mudah untuk mengelol dana zakat.

\section{KESIMPULAN}

Tugas amil adalah semua hal yang berhubungan dengan pengaturan zakat. Amil mengetahui orang-orang yang wajib zakat, macam-macam zakat yang diwajibkan, besar harta yang wajib dizakati, mengetahui para mustahik, jumlahnya, keperluan dan biaya yang cukup untuk mustahik. Kemudian tuganya utamanya adalah menghimpun, mencatat, mendo'akan muzaki, mengelola dan mendistribusikan kepada mustahik sesuai ketentun yang sudah di tetapkan berdsarkan al-Quran surat at-Taubah ayat 60. Begitupun dengan kedudukannya, amil memiliki kedudukan yang sangat penting dan mulia dihadapan Allah SWT.

Ada tiga unsur di dalam zakat yang saling berkaitan, yaitu muzaki (orang yang berzakat), mustahik (orang yang meneirma zakat), dan amil zakat (orang yang menggerakkan roda perzakatan). Amil zakat memiliki peranan yang sangat penting, karena amil yang menggerakan semua yang berkaitan dengan zakat. Begitupun peran amil yang ada di Laznas Al-Azhar, hasil kesimpulan yang penulis teliti, semua amil yang ada di Laznas Al-Azhar memiliki peran utama yang sama, yaitu memberikan edukasi kepada muzaki untuk bisa mengeluarkan zakat, khususnya zakat profesi. Dengan berbagi cara dan bidang masing-masing amil zakt yang ada di laznas Al-Azhar sudah memaksimalkan tugsnya secara profesional, artinya sesuai ketentuan yang sudah di atur oleh lembaga.

Berdsarkan rumusan masalah yaitu mengenai faktor pendukung dan faktor penghambat yang ada pada Laznas Al-Azhar maka penulis menyimpulkan bahwa faktor pendukungnya adalah adanya kesaman visi untuk melakukan edukasi dalam semua divisi. Caranya bisa melalui media dan berbagai program kajian rutin yang ada di laznas alazhar. Selain itu para amil juga menjaga komunikasi dan sosialisasi kepada muzaki yang sudah ada, salahsatunya kepada orang tua wali murid yang bersekolah di Al-Azhar. Kemudian dari segi penghambtnya yaitu dikarenakan pemahaman yang belum merata tentang zakat profesi dan kualitas perbedaan keimnn dari msing-msing individu, di tambah pern pemerintah/ulil amri yng belum memaksimalkan peran nya kepada zakat sehingga hampir disetiap lembaga zakat mengalami penurunan.

\section{REFERENSI}

Al-Qardhawi, Yusuf. 1976. Hukum Zakat, Hukum Komparatif Mengenai Status dan Filsafat Zakat Berdasarkan Quran dan Hadits, Terjemahan Bahsa indonesia. Bogor: Pustaka Litera Antar Nusa.

Departemen Pendidikan dan Kebudayaan. 1998. Kamus Besar Bahasa Indonesia. Jakarta: Balai Pustaka.

Depdikbud RI. 1991. Kamus Besar Bahasa Indonesia. Jakarta: Balai Pustaka.

Fakhrudin. 2008. Fiqih dan Manajemen Zakat di Indonesia. Malang: UIN Malang Press.

Hafidhuddin, Didin. 1998. Panduan Praktis tentang Zakat, Infak, dan sedekah. Jakarta: Gema Insani Press.

Hafidhuddin, Didin. 2002. Zakat dalam Perekonomian Modern. Jakarta: Gema Insani. Hasan, M. Ali. 2006. Zakat dan Infak Salah Satu Solusi Mengatasi Problema Sosial di Indonesia. Jakarta: Kencana Prenada Media Grup. 
Idris, Amirudin. 2016. Pengantar Ekonomi Sumber Daya Manusia. Yogyakarta: Deepublish.

Julijanto, Muhammad. 2015. Agama Agenda Demokrasi dan Perubahan Sosial. Yogyakarta: Deepublish.

Kementrian Agama RI. 2012. Modul Penyuluhan Zakat. Jakarta: Kementrian Agama RI.

Keraf, A. Sonny. 1998. Etika Bisnis, Tuntunan dan Relevansinya. Yogakarta: Kanisius.

Media Center. 2002. Kamus Ilmiyah Populer. Jakarta: Mitra Press.

Prasetyo, Yotok. 2018. Ekonomi Syariah. T.tp: Aria Mandiri Grup.

Suhardono, Edy. 2016. Teori Peran: Konsep, Devinisi dan Implikasinya. Jakarta: Gramedia Pustaka Utama.

Utomo, Setiawan Budi. 2009. Metode Praktis Penetapan Nisab Zakat. Bandung: PT. Mizan Pustaka.

Zen, Muhammad. Dkk. 2005. Zakat dan Wirausaha. Jakarta: Centre for Entrepreneurship Develepment.

Zen, Muhammad. 2014, Zakat Profesi Sebagai Distribusi Pendapatan Ekonomi Islam. Human Falah. Volume 1. No. 1: 68.

Zen, Muhammad. 2010. 24 Hours Of Contemporary Zakat: Tanya Jawab Seputar Keseharian Zakat. Ciputat: Indonesia Magnificence of Zakat.

Wawancara pribadi dengan Manager Funding Pubic Bapak Dika Lustian Pada Tanggal 11 Oktober 2019. 